\title{
Electrochemical Dechlorination of 3-chlorophenol with Palladium-Loaded Carbon Felt Electrode
}

\author{
Di Li ${ }^{1,2}$, Siqi Zhang ${ }^{1,2}$, Yingjia Chen ${ }^{1,2}$, Haiming Yang ${ }^{1,2, *}$, Xin Geng ${ }^{1,2}$, Suying Zhao ${ }^{1,2}$, Jiajun Li ${ }^{1,2}$ \\ and Lixiang $\mathrm{Li}^{1,2}$
}

1 School of Chemical Engineering, University of Science and Technology Liaoning, Anshan 114051, China; youxianglidi@163.com (D.L.); zhangsq2021347@163.com (S.Z.); chenyingjia126@163.com (Y.C.); gengxin60@163.com (X.G.); zhaoshuying912@sina.com (S.Z.); lijiajun0413@sina.com (J.L.); 1xli2005@126.com (L.L.)

2 Key Laboratory of Energy Materials and Electrochemistry Research Liaoning Province, University of Science and Technology Liaoning, Anshan 114051, China

* Correspondence: yanghaiming80@sina.com

check for updates

Citation: Li, D.; Zhang, S.; Chen, Y.; Yang, H.; Geng, X.; Zhao, S.; Li, J.; Li, L. Electrochemical Dechlorination of 3-chlorophenol with PalladiumLoaded Carbon Felt Electrode. Coatings 2021, 11, 1188. https:// doi.org/10.3390/coatings11101188

Academic Editor: Eva Pellicer

Received: 30 June 2021

Accepted: 14 September 2021

Published: 29 September 2021

Publisher's Note: MDPI stays neutral with regard to jurisdictional claims in published maps and institutional affiliations.

Copyright: (c) 2021 by the authors. Licensee MDPI, Basel, Switzerland. This article is an open access article distributed under the terms and conditions of the Creative Commons Attribution (CC BY) license (https:/ / creativecommons.org/licenses/by/ $4.0 /)$.

\begin{abstract}
Electrochemical dechlorination with Pd-loaded electrodes offers an effective method for detoxification of wastewater. Electro-reductive dechlorination of 3-chlorophenol (3-CP) with Pd loaded on carbon felt $(\mathrm{Pd} / \mathrm{CF})$ was investigated. Pd was loaded on carbon felt by electrolytic method. The prepared electrodes were characterized by XRD, SEM, EDS, S-TEM and CV. The sizes of the Pd particles loaded on CF were found in the range of 100-400 $\mathrm{nm}$. The preparing conditions including loading amount of $\mathrm{Pd}$ and loading currents were investigated. Moreover, the reduction conditions including electrolytes, reductive currents and recycle times were also studied. The Pd/CF cathodes with Pd loading of $0.5 \mathrm{mg} / \mathrm{cm}^{2}$, preparing current of $5 \mathrm{~mA}$, electrolyte concentration of $30 \mathrm{mmol} / \mathrm{L}$ $\mathrm{NaCl}$ and $30 \mathrm{mmol} / \mathrm{L} \mathrm{CH}_{3} \mathrm{COONa}$ were used to reduce 3-CP for dechlorination. When $\mathrm{CH}_{3} \mathrm{COONa}$ was used as the electrolyte, the current was $5 \mathrm{~mA}$, the initial $\mathrm{pH}$ was 7.5 , the initial 3-CP concentration was $1 \mathrm{mmol} / \mathrm{L}$ and the degradation rate of $3-\mathrm{CP}$ could reach $95.81 \%$ after reduction of $150 \mathrm{~min}$ under an argon atmosphere. The electrochemical reduction of 3-CP was confirmed to follow the first-order rate law. 3-CP was qualitatively dechlorinated to phenol on electrodes with Pd. The fact that active hydrogen formed on palladium during preliminary electrolysis could be proved by the dechlorinated 3-CP in non-electroreduction after preliminary electrolysis. A possible reduction pathway was proposed based on the results.
\end{abstract}

Keywords: electrolysis; dechlorination; palladium hydride; loading; reaction rate

\section{Introduction}

Over the last several decades, wastewaters containing persistent organic pollutants (POPs) have been causing a lot of environmental problems [1]. Chlorophenols (CPs), typical POPs, have been widely used in industry, agriculture and for domestic purposes over more than 50 years. It is well-known that they are toxic even at low levels. Thus, various techniques have been developed for the degradation of CPs, including biological, thermal, reduction and advanced oxidation processes (AOPs) [2-4]; for example, complete mineralization of 4-chlorophenol (4-CP) by $\mathrm{UV} /$ porous $\mathrm{TiO}_{2}$ layers and porous multiwalled carbon nanotube $\mathrm{TiO}_{2}$ composite layers were reported by Zouzelka and Rathousky [5,6]. Among these methods, electro-reductive dechlorination is one of the most promising [7], due to the following significant advantages: (i) effective dechlorination is possible at ambient temperatures, (ii) no highly active chemicals are required, (iii) selective removal of chlorine occurs while the organic skeleton remains to be digested by another cheap (e.g., bacterial) route, and (iv) no toxic by-products (i.e., chlorinated dioxins) are formed [6].

Electrocatalytic reductive dechlorination of monochlorophenols (2-CP and 4-CP) has been widely studied and proved to be efficient [8-13]. On the other hand, 3-CP, another 
monochlorophenol, which has been classified as priority pollutants by the U.S. Environmental Protection Agency (EPA) [14], was also harmful to humans and needed to be treated [15]. Several processes have been used to degrade $3-\mathrm{CP}$, such as electrocatalytic oxidation, ultrasound-assisted electrocatalytic oxidation, photocatalytic $\mathrm{TiO}_{2}$, and electrochemicalassisted photocatalytic processes [16-20]. Electro-catalytic reductive dechlorination was one of the most promising and attractive [7]. Pd was considered as the best catalyst for electro-reduction dechlorination due to its unique function in adsorption of hydrogen [21]. Moreover, aside from the retardation of the $\mathrm{H}$ combination, the $\mathrm{H}_{2}$ generated from the cathode could be further adsorbed on $\mathrm{Pd}$ and dissociated into two atomic $\mathrm{H}$, reducing the contaminant [22]. However, the high cost of the pure Pd cathode was a particular disadvantage for use [21]. Thus, Pd loaded on different materials such Ti mesh, carbon felt, and so on were investigated [23-25]. The most activity catalyst for the electro-dechlorination of chlorinated organic compounds have been reported as palladium-loaded catalysts [26-29]. Though the electro-reduction of 3-CP by Pd loading on carbon felt was reported by Cai et al. [24], important and detailed information about reduction affecters, such as the preparing conditions of Pd loading cathodes, reduction conditions, and so on, were still unknown. Thus, in this paper, we report the electro-dechlorination of 3-CP on Pd-loaded carbon felt $(\mathrm{Pd} / \mathrm{CF})$ electrodes, focusing on the cathode preparing conditions, affect factors, reaction kinetics, and dechlorination mechanism.

\section{Materials and Methods}

\subsection{Materials and Instruments}

Carbon felt was supplied by Gun-Ei Chemicals Industries Co. (Takasaki, Japan). Its areal weight was $274 \mathrm{~g} / \mathrm{m}^{2}$ and the thickness was $5 \mathrm{~mm}$. Palladium chloride and 3-CP were purchased from Wako Chemicals. Water purified by Milli-Q (Millipore) was used for the electrolyte solution.

A H-type glass cell separated with the N117 membrane was employed as shown in Figure 1. The capacity was $100 \mathrm{~mL}$ for each compartment. Electrolysis processes were carried out with the aid of Potentiostat/Galvanostat HABF-501 (Hokuto Denko Co., Tokyo, Japan).

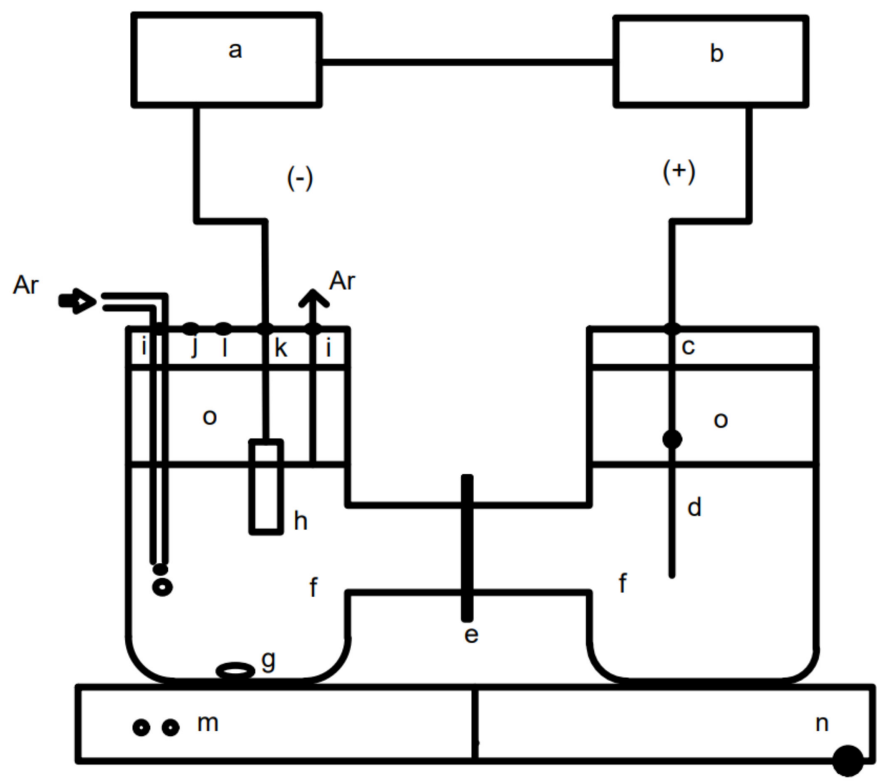

Figure 1. Experimental apparatus for dechlorination: (a) digital coulometer, (b) DC power supplier, (c) anode hole, (d) anode, (e) Nafion membrane-N117, (f) electrolytic solution, (g) teflon-coated magnet bar, (h) cathode, (i) gas hole, (j) sampling hole, (k) cathode hole, (1) reference electrode hole, (m) magnetic stirrer, (n) packing block, and (o) glass tube. 


\subsection{Electroloading of Palladium on Carbon Felt}

The loading of palladium was executed by electrolytic means. Carbon felt cut into $25 \times 15 \times 5 \mathrm{~mm}$ was dipped into $2000 \mathrm{mmol} / \mathrm{L}$ sulfuric acid over one night and rinsed with water. One piece of the felt was connected with SUS wire and used as a cathode. The immersed depth of the cathode was $20 \mathrm{~mm}$ and, therefore, the electro-loaded surface was $20 \times 15 \mathrm{~mm}$. The electrolyte solution was $30 \mathrm{mmol} / \mathrm{L} \mathrm{NaCl}$ for certain amount of palladium chloride, and the solution was stirred with magnet stirrer. The carbon felt electrode was used as a cathode and platinum foil was used as an anode. Both electrolytic solutions were purged with argon. The current in electro-loading was $5 \mathrm{~mA}$ and the reaction time was $30 \mathrm{~min}$. Then, galvanostatic electro-plating was continued until the $\mathrm{Pd}^{2+}$ ion in the solution was consumed. After electro-loading, the amount of residual $\mathrm{Pd}^{2+}$ in the reaction solution was analyzed by ICP-Mass. The results showed that for each case, at least above $99.5 \%$ of $\mathrm{Pd}^{2+}$ was loaded on $\mathrm{CF}$.

\subsection{Electrolysis and Non-Electrolysis of 3-CP}

After purging the electrolyte solution with argon, a given amount of 3-CP was injected into catholyte solution. Electrolysis was performed in galvanostatic mode under maximum stirring with magnet stirrer under certain currents. Non-electrolysis was performed under maximum stirring with magnet stirrer. Before non-electrolysis, the $\mathrm{Pd} / \mathrm{CF}$ cathodes were prepared under certain currents for 90 mins without 3-CP. The proceeding of dechlorination was monitored by quantitative analysis of $3-\mathrm{CP}$ and phenol (the single product) with HPLC [24].

\section{Results and Discussion}

\subsection{The Characterization of $P d / C F$ Cathode}

In order to obtain the information of Pd loading on $\mathrm{CF}, \mathrm{CF}$ and $\mathrm{Pd} / \mathrm{CF}$ cathodes were characterized by XRD, SEM, EDS, S-TEM, and CV, as shown in Figures 2-6. As shown in Figure 2, the diffraction peaks corresponding to Pd were found after electro-deposition of Pd on CF, indicating that Pd might be successfully loaded on CF. It can be seen in Figure 3 that lots of particles scatter over the surface of CF. With the results of EDS in Figure 4, the small particles could be confirmed as Pd particles. In Figure 5, the sizes of the Pd particles were found in the range of $100-400 \mathrm{~nm}$. The fine scattering nano Pd particles might lead to good electro-dechlorination of 3-CP.

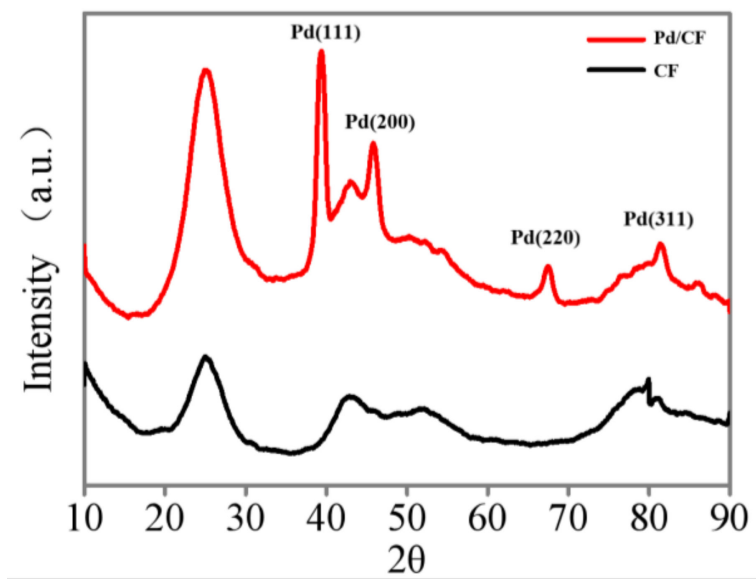

Figure 2. XRD of carbon felt electrode and Pd-loaded carbon felt electrode $\left(0.5 \mathrm{mg} / \mathrm{cm}^{2}\right)$. 


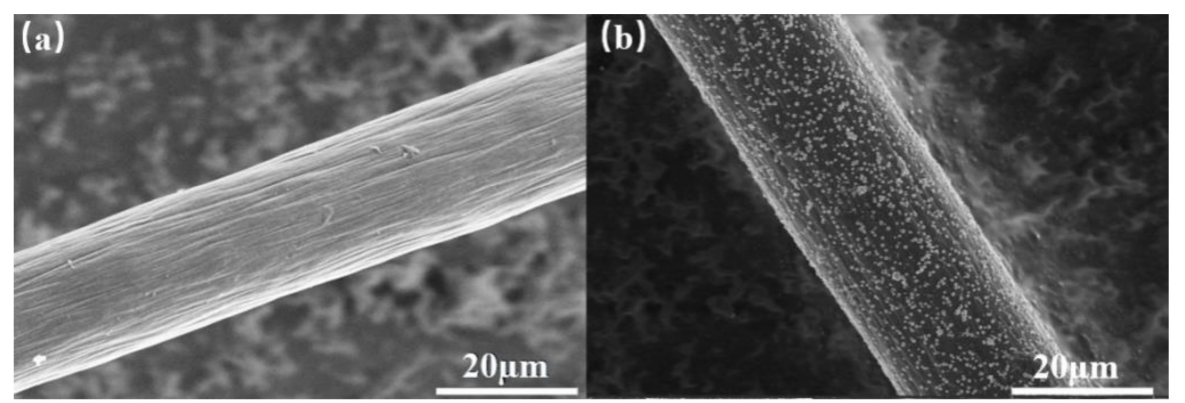

Figure 3. SEM of cathode: (a) raw carbon felt electrode and (b) Pd-loaded carbon felt electrode $\left(0.5 \mathrm{mg} / \mathrm{cm}^{2}\right)$.
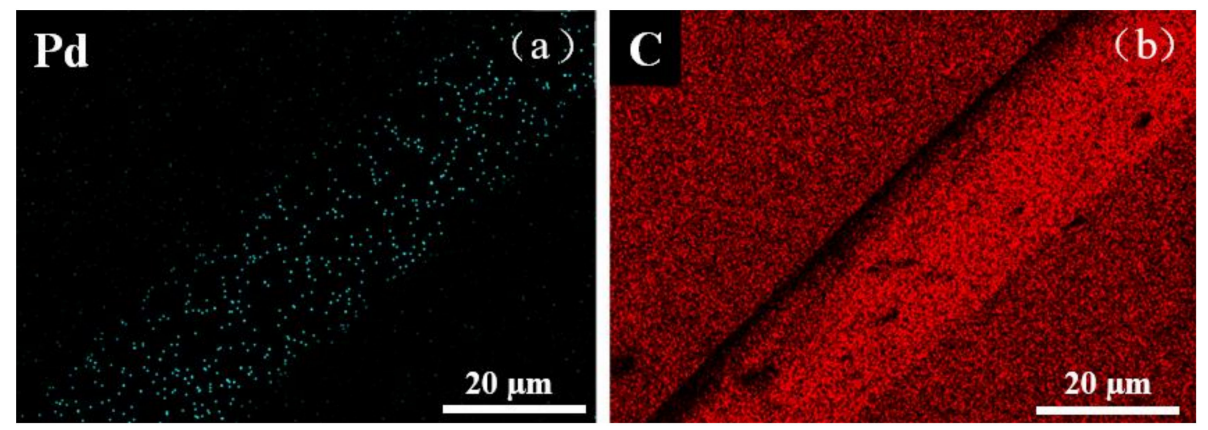

Figure 4. EDS of Pd-loaded carbon felt electrode $\left(0.5 \mathrm{mg} / \mathrm{cm}^{2}\right)$, (a) Pd element scatter, (b) C element scatter.

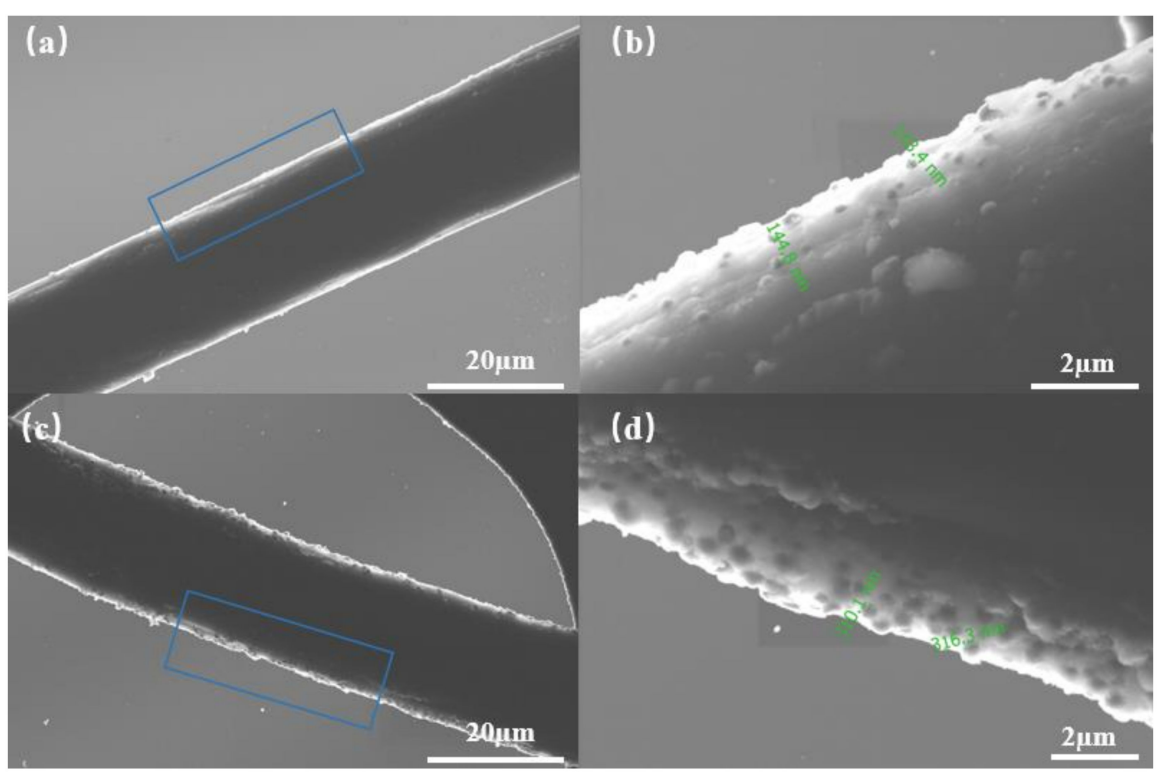

Figure 5. S-TEM of cathodes with different amount of Pd loading. (a,b) Pd-loaded carbon felt electrode $\left(0.25 \mathrm{mg} / \mathrm{cm}^{2}\right)$; (c,d) Pd-loaded carbon felt electrode $\left(0.5 \mathrm{mg} / \mathrm{cm}^{2}\right)$.

The $\mathrm{H}$ atom adsorbed $\left(\mathrm{H}_{\mathrm{ads}}\right)$ on the Pd surface has been considered as the key species in electro-dechlorination [30]. Thus, $\mathrm{CV}$ characterizations of $\mathrm{Pd} / \mathrm{CF}$ with different $\mathrm{Pd}$ loading were obtained in order to study the catalytic ability of these carbon-supported catalysts. As shown in Figure 6, an oxidation peak was observed in the CVs of bare carbon supports from $-1.5 \mathrm{~V}$ to $-0.75 \mathrm{~V}$, attributing to the water decomposed into $\mathrm{H}_{2}$ and $\mathrm{OH}^{-}$ $\left(2 \mathrm{H}_{2} \mathrm{O}+2 \mathrm{e}=\mathrm{H}_{2}+\mathrm{OH}^{-}, \varphi_{\mathrm{H} 2 \mathrm{O} / \mathrm{OH}-}=-0.828 \mathrm{~V}\right.$ vs. NHE$)$. After the deposition of the $\mathrm{Pd}$ catalyst on CF support, the current density of oxidation peak increased slightly with the increase of the amount of Pd loaded on CF, which was consistent with the mechanism of 
water split by the Pd catalyzer. Furthermore, the hydrogen adsorption-reduction peak was also observed at $0.25 \mathrm{~V}$, and the peak current density was strengthened with the amount of $\mathrm{Pd}$ on CF. This result might indicate that Pd loading would improve the electrocatalytic ability of these Pd-loading catalysts. However, for all cases, no obvious reduction peaks of 3-CP in the range of potential window was observed. Based on these results, the dechlorination could not be identified by CVs in this work.

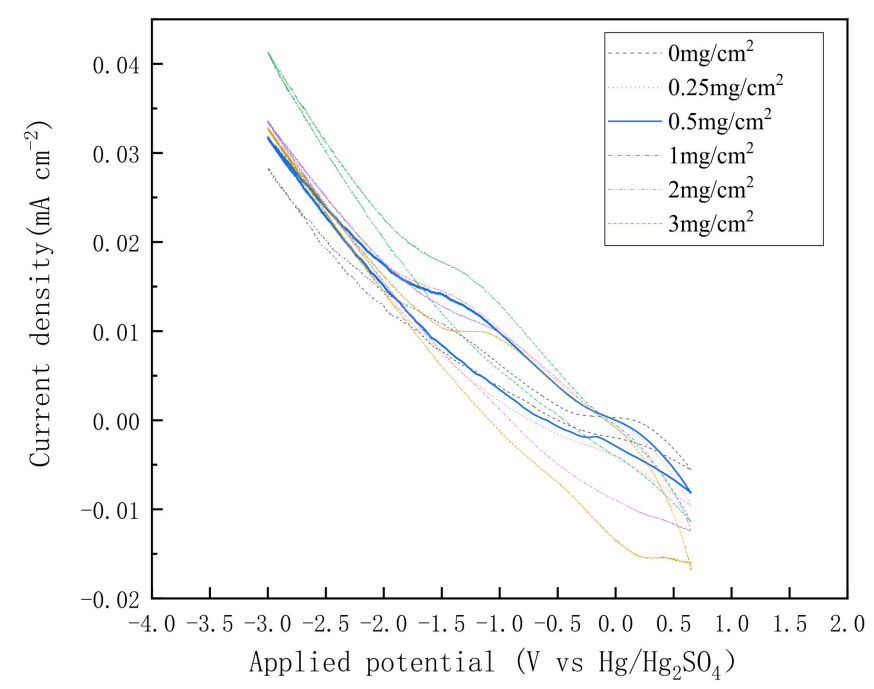

Figure 6. Cyclic voltammogram (CV) curves of $\mathrm{Pd} / \mathrm{CF}$, electrolyte of $30 \mathrm{mM} \mathrm{CH}_{3} \mathrm{COONa}$, scan rate of $0.03 \mathrm{~V} / \mathrm{s}$, number of the scans 6 , and $1 \mathrm{mM} 3-\mathrm{CP}$.

The $\mathrm{CV}$ processes revealed that activated $\mathrm{H}$ atoms were adsorbed on $\mathrm{Pd} / \mathrm{CF}$ electrode along with the electrolytic process. Because hydrogen oxidation was inhibited by coverage of $\mathrm{H}_{2}$ on the surface of Pd particles, hydrogen oxidation was not observed. Though for all cases no obvious reduction peaks of 3-CP in the range of potential windows was observed, the strength of peaks for reduction peak of $\mathrm{H}^{+}$suggested that the $\mathrm{Pd}$ loading would improve the electrocatalytic ability of 3-CP reduction. Accordingly, the dechlorination efficiency was also closely related to the combination of activated $\mathrm{H}$ atoms and the $\mathrm{Pd}$ catalyzer.

\subsection{Influence of the Loaded Amount of Pd}

Pd was widely used as a catalyst for the hydrogenation of chlorinated organic compounds [31,32], and the activity for a given reaction can be affected significantly by the different amount of Pd loaded [33]. Thus, carbon felt with different amounts of Pd loaded were employed as cathodes for the dechlorination of 3-CP.

The results were shown in Figure 7. Once Pd was loaded $\left(0.25 \mathrm{mg} / \mathrm{cm}^{2}\right)$ onto the carbon cathode, the removal rates of 3-CP increased markedly. This result could be rationalized by the idea that $\mathrm{Pd}$ particles loaded on the surface can enhance the reductive ability of the cathodes [34].

As shown in Figure S2, the removal rates of 3-CP increased with the increase of $\mathrm{Pd}$ loading and reached the value $95.81 \%$ at a loading of approximately $0.5 \mathrm{mg} / \mathrm{cm}^{2} \mathrm{Pd}$ on carbon felt; then, the removal rates were kept around $95 \%$ with further increase of $\mathrm{Pd}$ loading. As shown in Figure 5, for lower Pd loadings $\left(0.25 \mathrm{mg} / \mathrm{cm}^{2}\right)$, both the size and the number of the Pd particles were smaller (about $140 \mathrm{~nm}$ in diameter) than those (about $320 \mathrm{~nm}$ in diameter) of the best Pd loadings $\left(0.5 \mathrm{mg} / \mathrm{cm}^{2}\right)$, indicating that Pd particle size might not be most important for the electro-catalyst ability, while the number of the Pd particles and particle size together, which would correspond to the surface of Pd loaded on $\mathrm{CF}$, might be the key roles for the dechlorination of 3-CP. 


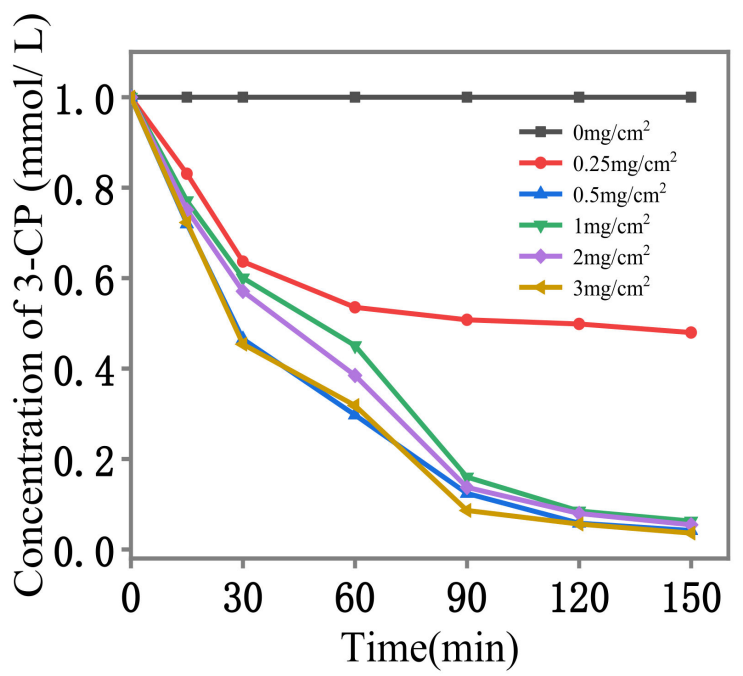

Figure 7. Effect of loading amount of Pd on variation of the concentration of 3-CP.

\subsection{Influence of the Loading Currents}

When the Pd/CF cathodes were prepared by electroloading method, the current was an important factor. Thus, the influence of the currents on the degradation of 3-CP were investigated. As shown in Figures 8 and S3, firstly the removal rates of 3-CP increased with the increase of loading currents from $1 \mathrm{~mA}$ to $5 \mathrm{~mA}$, then an obvious decrease appeared corresponding to the loading current $10 \mathrm{~mA}$, and the removal rates kept increasing with the increase of loading currents. Since the loading current might affect the morphology of $\mathrm{Pd} / \mathrm{CF}$, the SEM of $\mathrm{Pd} / \mathrm{CF}$ cathodes prepared under $1 \mathrm{~mA}, 5 \mathrm{~mA}, 10 \mathrm{~mA}$, and $50 \mathrm{~mA}$ were investigated. As shown in Figures 3 and 9, compared to the cases of $\mathrm{Pd} / \mathrm{CF}$ with a preparing current of $1 \mathrm{~mA}$ and $10 \mathrm{~mA}$, the better degree of dispersion of the Pd particles of $\mathrm{Pd} / \mathrm{CF}$ with a preparing current of $5 \mathrm{~mA}$ was observed. The degree of dispersion for $\mathrm{Pd} / \mathrm{CF}$ with a preparing current of $50 \mathrm{~mA}$ was similar to that of $\mathrm{Pd} / \mathrm{CF}$ with a preparing current of $5 \mathrm{~mA}$. While for the case of $\mathrm{Pd} / \mathrm{CF}$ with a preparing current of $1 \mathrm{~mA}$, several large $\mathrm{Pd}$ particles with a size of about $10 \mu \mathrm{m}$ were found, and for the case of a preparing current of $10 \mathrm{~mA}$, there was also one large Pd particle with a size of about $5 \mu \mathrm{m}$. These results suggested that the degradation rates might depend on the degree of Pd particle dispersion.

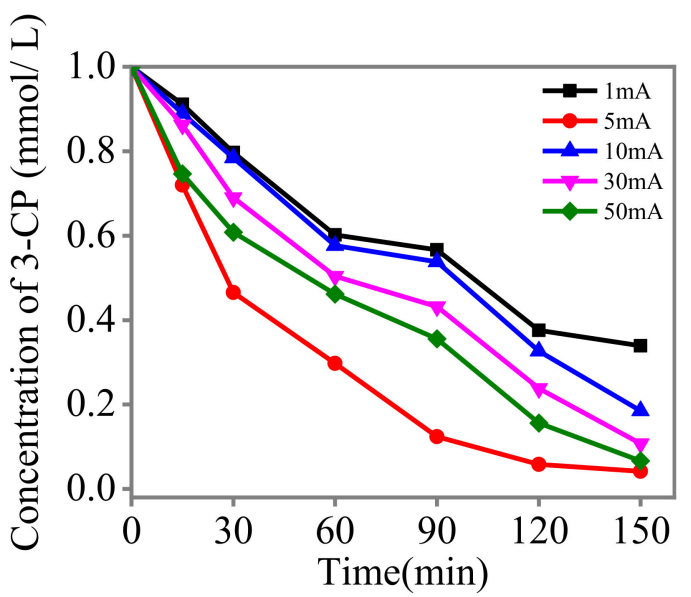

Figure 8. Effect of the currents for the variation of the 3-CP concentration. 


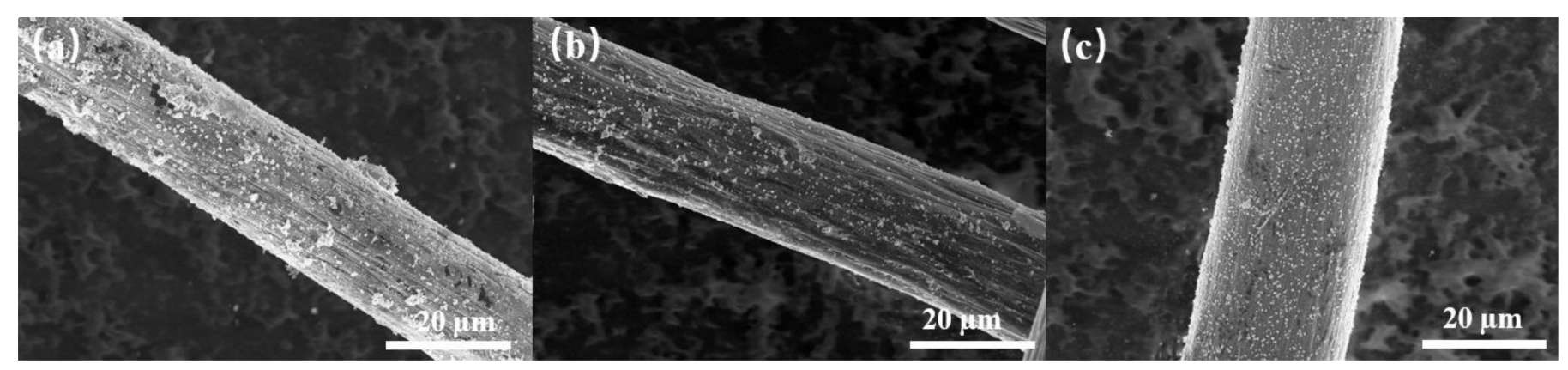

Figure 9. SEM of cathodes prepared under different currents: (a) Pd-loaded carbon felt electrode (1 mA), (b) Pd-loaded carbon felt electrode (10 mA), and (c) Pd-loaded graphite felt electrode $(50 \mathrm{~mA}),\left(0.5 \mathrm{mg} / \mathrm{cm}^{2}\right)$.

\subsection{Influence of the Electrolytes}

In the reduction, the electrolytes might affect the reduction of 3-CP; thus, $\mathrm{NaCl}, \mathrm{Na}_{2} \mathrm{SO}_{4}$, and $\mathrm{CH}_{3} \mathrm{COONa}$ were investigated as electrolytes. As shown in Figures 10 and $\mathrm{S} 4$, the removal rates of 3-CP increased in this order: $\mathrm{NaCl}, \mathrm{Na}_{2} \mathrm{SO}_{4}$, and $\mathrm{CH}_{3} \mathrm{COONa}$. The lowest removal rate corresponded to $\mathrm{NaCl}$ and was $49.99 \%$, the highest removal rate of 3-CP was $95.81 \%$ corresponding to $\mathrm{CH}_{3} \mathrm{COONa}$. According to $\mathrm{Xu}$ 's investigation of $\mathrm{Pd} / \mathrm{C}$, there were $\mathrm{Pd}^{2+}$ ions on the surface of the $\mathrm{Pd}$ particle [30]. The $\mathrm{Cl}^{-}$ions might connect with $\mathrm{Pd}^{2+}$ to form a $\mathrm{Pd}-\mathrm{Cl}$ bond, resulting in reducing the formation of $\mathrm{H}_{\mathrm{ads}}$ and absorption of 3-CP. Thus, the highly negative influence of $\mathrm{NaCl}$ on the reduction of 3-CP might be explained.

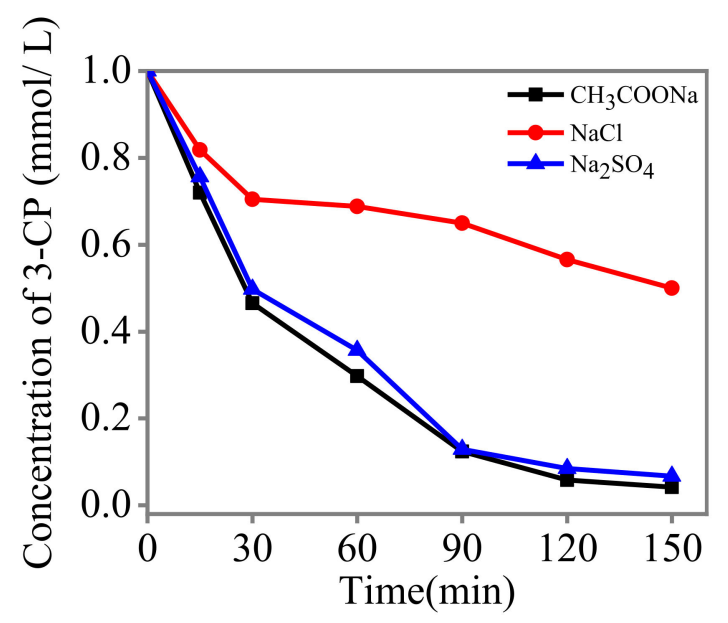

Figure 10. Effect of different electrolytes on the variation of the 3-CP concentration.

\subsection{Influence of the Concentrations of Reduction Electrolyte}

The variations of the 3-CP concentrations were shown in Figure 11. For most cases, 3-CP decreased smoothly. As shown in Figures 11 and S5, the reduction of 3-CP corresponding to $30 \mathrm{mM} \mathrm{CH}_{3} \mathrm{COONa}$ was obviously better than other cases. This result could be rationalized by the idea that the concentration of $\mathrm{CH}_{3} \mathrm{COONa}$ would result in higher conductivity, which would be beneficial for the reduction reaction; and the $\mathrm{CH}_{3} \mathrm{COO}^{-}$ might also react with $\mathrm{Pd}^{2+}$, resulting in reducing the reduction of 3-CP. 


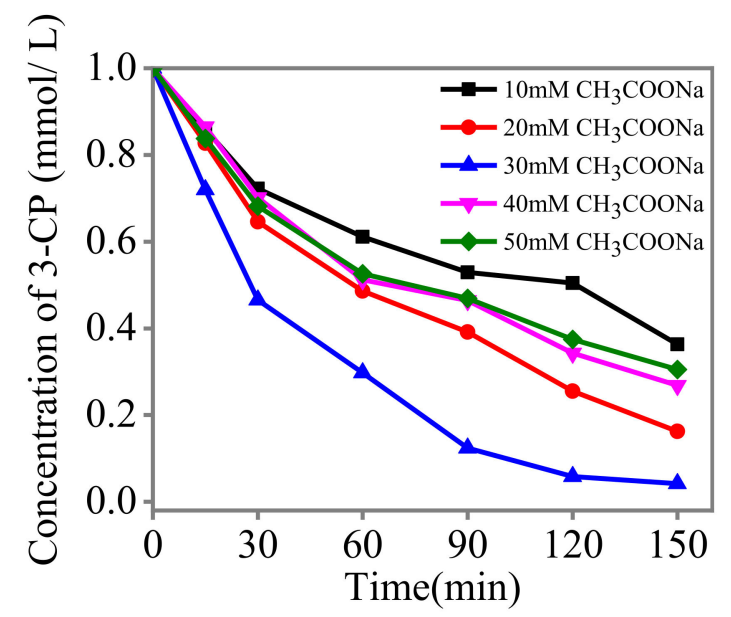

Figure 11. Effect of concentrations of $\mathrm{CH}_{3} \mathrm{COONa}$ on variation of the 3-CP concentration.

\subsection{Influence of the Reducing Currents}

When 3-CP is electro-chemically reduced, the reducing currents could be an important factor. Thus, the influence of the reduction currents on the degradation of 3-CP were investigated. As shown in Figures 12 and S6, for the reducing current of $1 \mathrm{~mA}$, the lowest removal rate of $5.97 \%$ was obtained; then, with the increase of the reducing current to $5 \mathrm{~mA}$, the highest removal rate of $95.81 \%$ was obtained; the removal rates decreased in the range of reducing currents from $5 \mathrm{~mA}$ to $20 \mathrm{~mA}$. At the lower reducing current, there was not enough highly reactive $\mathrm{H}_{\mathrm{abs}}$ bound to the $\mathrm{Pd}$ surface for dechlorination. At the higher reducing current, the local current density for $\mathrm{H}^{+}$reduction was too high, resulting in excessive hydrogen gas evolution, thus disturbing the mass transfer of 3-CP to the surface of the Pd-loaded carbon felt cathode [24].

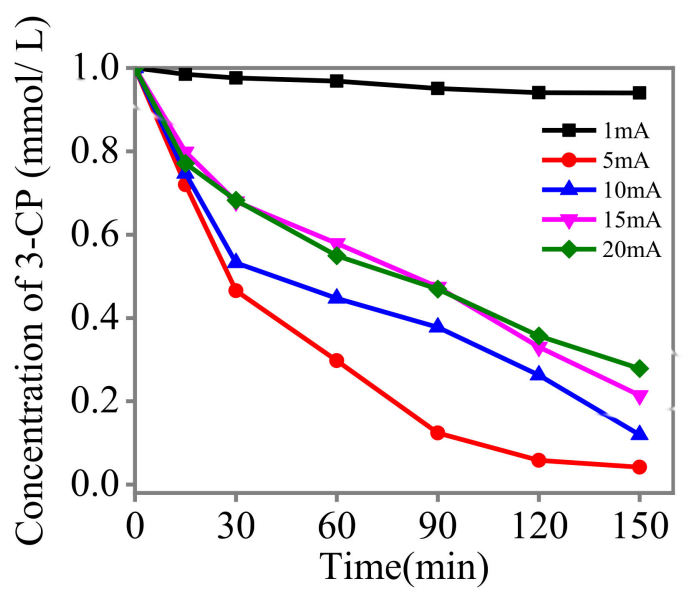

Figure 12. Effect of reduction current on the variation of the 3-CP concentration.

\subsection{Kinetics of 3-CP Degradation}

The 3-CP decay curve under the best condition, as shown in Figure 12, was exponential degradation. Consequently, we fit the data to the integral rate equation for the first-order reaction, shown as Equation (1):

$$
\ln \left(C_{0} / C\right)=k t
$$

where $C, C_{0}, k$, and $t$ denote the concentration of $3-C P$ at the given reaction time, at $t=0$, the rate constant, and the reaction time, respectively.

In consequence, for the set of data concerning decay, a straight line with good correlation was obtained, as shown in Figure 13. This result indicates that 3-CP reacted per the 
first-order rate law. The apparent rate constants, $k$, for the decay of 3-CP was calculated from the slope to be $k=2.23 \times 10^{-2} \mathrm{~min}^{-1}$.

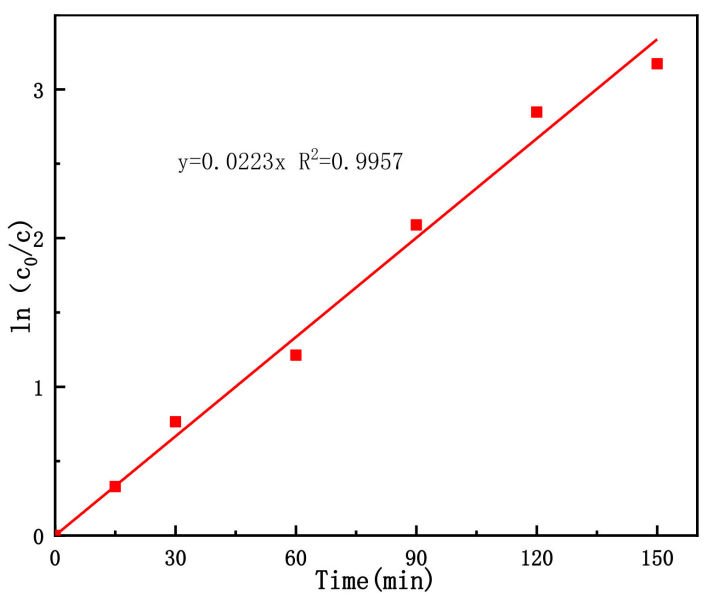

Figure 13. Kinetical plots of 3-CP degradation in optimum condition.

\subsection{Mechanism and Possible Degradation Pathways}

In order to get the mechanistic information about the indirect reduction of 3-CP on the Pd surface, the effect of preliminary electrolysis was examined. Figure 14 showed example of the non-electroreduction of 3-CP. After preliminary electrolysis, about $1 \mathrm{mmol}$ of the substrate was introduced and stirred to contact with the activated electrode. For all the cases mentioned above, it decreased in 10 minutes to reach a constant level, meaning approximately $20 \%$ of $3-\mathrm{CP}$ was already dechlorinated. This implied that the reactive species responsible for the dechlorination of 3-CP would be formed during preliminary electrolysis. The most probable seemed $(\mathrm{Pd}) \mathrm{xH}$, which might result from the adsorption of electrogenerated hydrogen on metallic $\mathrm{Pd}$ [24]. The possible reduction pathway was proposed in Scheme 1.

$$
\begin{gathered}
\mathrm{nPd}^{0}+2 \mathrm{H}^{+}+2 \mathrm{e}^{-} \rightarrow(\mathrm{Pd})_{\mathrm{n}}-\mathrm{H}_{2 \mathrm{ads}} \\
(\mathrm{Pd})_{\mathrm{n}}-\mathrm{H}_{2 \mathrm{ads}}+3-\mathrm{CP} \rightarrow \mathrm{P}+\left(\mathrm{Pd}^{0}\right)_{\mathrm{n}}+\mathrm{H}^{+}+\mathrm{Cl}^{-}
\end{gathered}
$$

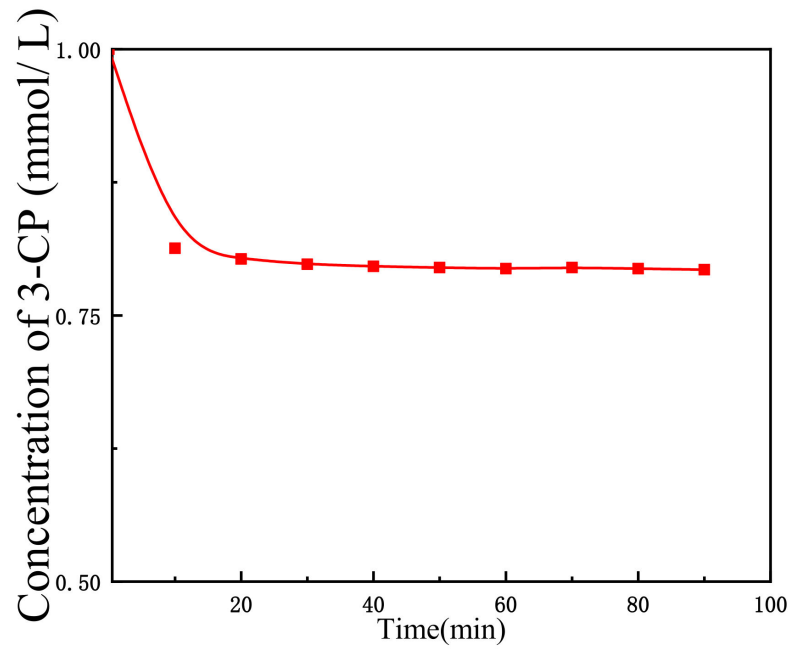

Figure 14. The variation of 3-CP in non-electrolytic dechlorination after preliminary electrolysis. 


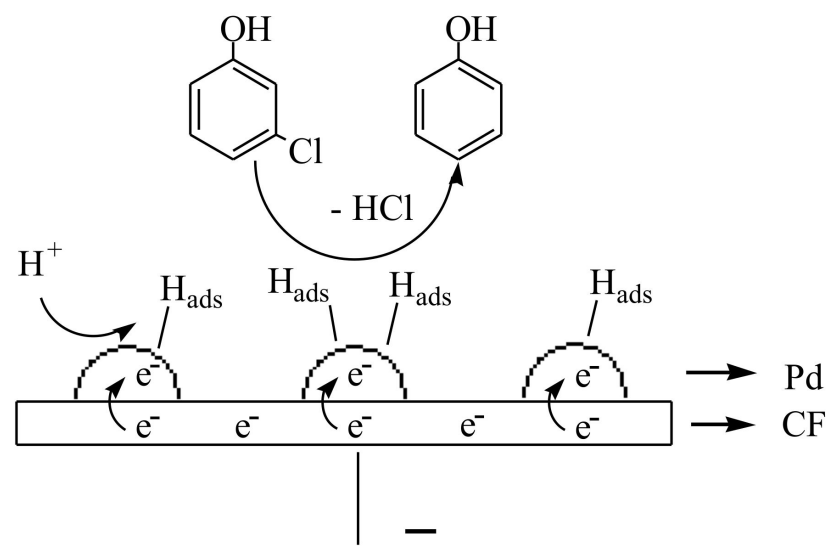

Scheme 1. Indirect reduction of monochlorophenol on Pd-loaded carbon felt electrode.

\subsection{Reuse of $\mathrm{Pd} / \mathrm{CF}$}

To assess the stability of the Pd catalyst, Pd/CF electrodes were repeatedly used in the electro-reductive dechlorination. The results were summarized in Figure 15. Up to 5 times of use, the dechlorination rates were found to decrease from $95.8 \%$ to $92.3 \%$. Thus, it was confirmed that the Pd catalyst possessed a satisfactory durability under the present condition.

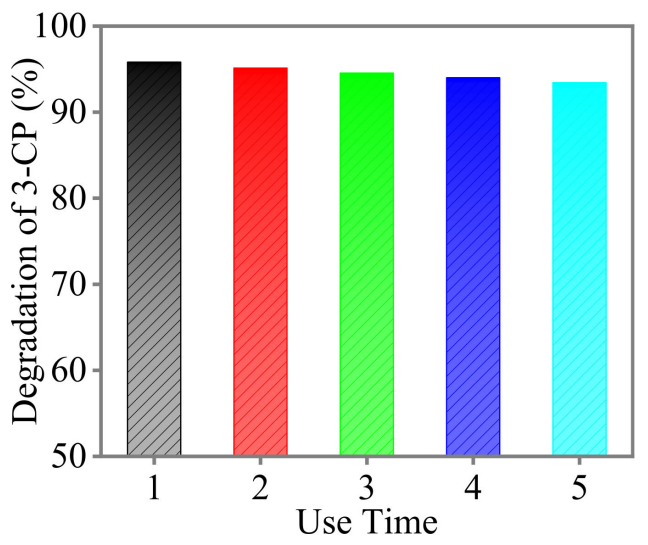

Figure 15. Reuse of Pd/CF in electro-reductive dechlorination.

\subsection{Comparison with Other Processes}

In Table 1, the representative performance on the degradation of 3-CP by using ultrasound-assisted electrocatalytic oxidation [16], electrocatalytic oxidation [17], electrochemical and photocatalytic process [18], photo-catalyst [19], electro-Fenton [20], and electro-reduction reported by Cai [26] were summarized along with that by electro-reduction. It should be remarked that most of solution treated by other methods were comparatively dilute. As a whole, electro-reduction seems considerably superior to ultrasound-assisted electrocatalytic oxidation, electrochemical and photocatalytic processes, and photocatalysts, substantially comparable to the electrocatalytic oxidation, electro-Fenton process and electro-reduction reported by Cai. After repeated use, the decrease in removal rate for this work was also comparable to electrocatalytic oxidation. 
Table 1. Comparison of electro-reduction with other processes for degradation of 3-CP. (1) 3 -CP removal/reaction time $(\% / \mathrm{min})$.

\begin{tabular}{|c|c|c|c|c|c|c|}
\hline$C_{0} / \mathrm{mM}$ & Method & $\mathrm{pH}$ & $(1)^{a}$ & $k / 10^{-2} \min ^{-1}$ & $\begin{array}{l}\text { Decrease in Removal } \\
\text { Rate }(\%) / \text { Reuse Times }\end{array}$ & References \\
\hline 1.00 & electroreduction & 7.5 & $96 / 150$ & 2.23 & $3 / 5$ & This work \\
\hline 1.00 & ultrasound assisted electrocatalytic oxidation & 9.1 & $35 / 60$ & & & [16] \\
\hline 0.39 & $\begin{array}{c}\text { electrocatalytic oxidation } \\
\text { electrochemical and }\end{array}$ & 5 & $98 / 120$ & 3.84 & & [17] \\
\hline 0.39 & $\begin{array}{c}\text { photocatalytic process (tungsten supported } \\
\text { ZnO/Solar) }\end{array}$ & & $84 / 150$ & 1.10 & & [18] \\
\hline 0.08 & $\begin{array}{c}\text { photocatalytic } \mathrm{TiO}_{2} \\
(0.2 \mathrm{~g} / \mathrm{L}) \\
\text { UV energy }\end{array}$ & 7.0 & $77 / 300$ & & $4 / 5$ & [19] \\
\hline 0.50 & electroreduction & 4.0 & $98 /$ & & $3 / 4$ & [24] \\
\hline
\end{tabular}

\section{Conclusions}

3-CP could be dechorinated by the electro-reductive method with Pd loaded on carbon felt. And Phenol and chloride ions were found to be the products. The electrochemical dechlorination of 3-CP was confirmed to follow the first-order rate law. Both the size and number of Pd particles would affect the dechlorination rate of 3-CP. The fact of active hydrogen formed on palladium during preliminary electrolysis could be proved by the dechlorinated 3-CP in non-electroreduction after preliminary electrolysis, indicating that indirect reduction of 3-CP by $\mathrm{Pd} / \mathrm{CF}$ should be one of the possible reaction pathways.

Supplementary Materials: The following are available online at https:/ /www.mdpi.com/article/10 .3390 / coatings11101188/s1, Figure S1: SEM of cathode (a) Raw carbon felt electrode, (b) Pd loaded carbon felt electrode $\left(0.5 \mathrm{mg} / \mathrm{cm}^{2}\right)$. Figure S2: Effect of loading amount of $\mathrm{Pd}$ on the removal rates of 3-CP, Figure S3: Effect of the currents for the preparation electrode on the removal rates of 3-CP, Figure S4: Effect of different electrolytes on the removal rates of 3-CP, Figure S5: Effect of concentrations of $\mathrm{CH} 3 \mathrm{COONa}$ on the removal rates of 3-CP, Figure S6: Effect of reduction current on The removal rates of 3-CP.

Author Contributions: Conceptualization, H.Y. and S.Z. (Siqi Zhang); methodology, D.L.; Formal analysis, D.L. and Y.C.; Data curation, J.L. and S.Z. (Suying Zhao); Writing-original draft preparation, H.Y. and D.L.; Supervision, X.G. and L.L. All authors have read and agreed to the published version of the manuscript.

Funding: This research was funded by the National Natural Science Foundation of China (Grant No. 51308276); Scientific Research Foundation for Doctors of Liaoning Province (Grant No. 20141123); Growth Plan for Distinguished Young Scholars in Colleges and Universities of Liaoning Province China (LJQ2015055); Innovative Research Team in Colleges and Universities of Liaoning Province China (2017TD02); and Foundation of Liaoning Province education department, China (2020LNJC06). The youth backbone project of Liaoning University of science and technology (601011507-18), key research and development program of Liaoning Province China (2018304017).

Acknowledgments: Special thanks go to Meguru Tezuka and Atsushi Matsunaga (Saitama Institute of Technology) for their comments and support.

Conflicts of Interest: The authors declare no conflict of interest.

\section{References}

1. Marye, A.F.; Maria, T.D. Heterogeneous photocatalysis. Chem. Rev. 1993, 93, 341-342.

2. Velasco, L.F.; Parra, J.B.; Ania, C.O. Role of activated carbon features on the photocatalytic degradation of phenol. Appl. Surf. Sci. 2010, 256, 5254-5258. [CrossRef]

3. Aken, V.; Lambert, N.; Van den Broeck, R.; Degrève, J. Advances in ozonation and biodegradation processes to enhance chlorophenol abatement in multisubstrate wastewaters: A review. Environ. Sci. Water Res. Technol. 2019, 3, 444-481. [CrossRef]

4. Garba, Z.N.; Zhou, W.M.; Lawan, I.; Xiao, W.; Zhang, M.X.; Wang, L.W.; Chen, L.H. An overview of chlorophenols as contaminants and their removal from wastewater by adsorption: A review, Review of biodegradation of chlorophenol organic pollutants. J. Environ. Manag. 2019, 241, 59-75. [CrossRef] 
5. Zouzelka, R.; Remzova, M.; Brabec, L.; Rathousky, J. Photocatalytic performance of porous $\mathrm{TiO}_{2}$ layers prepared by quantitative electrophoretic deposition from organic solvents. Appl. Catal. B Environ. 2018, 227, 70-78. [CrossRef]

6. Zouzelka, R.; Kusumawati, Y.; Remzova, M.; Rathousky, J.; Pauporté, T. Photocatalytic activity of porous multiwalled carbon nanotube-TiO2 composite layers for pollutant degradation. J. Hazard. Mater. 2016, 317, 52-59. [CrossRef]

7. Yang, B.; Yu, G. Electrocatalytic reductive dechlorination of 2,4,5-PCB in aqueous solution by palladium-modifified titanium mesh as the cathode. Acta Phys. Chim. Sin. 2006, 22, 306-311. [CrossRef]

8. Ukisu, Y.; Iimura, S.; Uchida, R. Catalytic dechlorination of polychlorinated biphenyls with carbon-supported noble metal catalysts under mild conditions. Chemosphere 1996, 33, 1523-1530. [CrossRef]

9. Arellano-González, M.A.; Texier, A.-C.; Lartundo-Rojas, L. Electrochemical Dechlorination of 2-Chlorophenol on Pd/Ti, Ni/Ti and Pd-Ni Alloy/Ti Electrodes. J. Electrochem. Soc. 2015, 162, E223-E230. [CrossRef]

10. Bo, Y.; Shu, W.; Gang, Y.; Zhou, Y. Separation and Purification Technology, Electrocatalytic reduction of 2-chlorobiphenyl in contaminated water using palladium-modified electrode. Sep. Purif. Technol. 2008, 63, 353-359.

11. Shu, X.Y.; Yang, Q.; Yao, F.B.; Zhong, Y.; Ren, W.C.; Chen, F. Electrocatalytic hydrodechlorination of 4-chlorophenol on Pd supported multi-walled carbon nanotubes particle electrodes. Chem. Eng. J. 2019, 358, 903-911. [CrossRef]

12. Wu, Y.F.; Gan, L.; Zhang, S.P.; Song, H.O.; Lu, C. Carbon-nanotube-doped Pd-Ni bimetallic three-dimensional electrode for electrocatalytic hydrodechlorination of 4-chlorophenol: Enhanced activity and stability. J. Hazard. Mater. 2018, 356, 17-25. [CrossRef]

13. Cheng, I.F.; Fernando, Q.; Korte, N. Electrochemical Dechlorination of 4-Chlorophenol to Phenol. Environ. Sci. Technol. 1997, 31, 1074-1078. [CrossRef]

14. Luise, W.; Peter, P.; Monika, M. Determination of chlorophenols in soils using accelerated solvent extraction combined with solid-Phase microextraction. Anal. Chem. 2000, 72, 546-551.

15. Grace, W.M.; Natasha, T.; Greg, M.S. Electro-oxidation and amperometric detection of chlorinated phenols at boron-doped diamond electrodes: A comparison of microcrystalline and nanocrystalline thin films. Environ. Sci. Technol. 2004, 38, 3674-3682.

16. Zhu, R.Y.; Chen, X.M. Ultrasound assisted electrocatalytic oxidation of 3-chlorophenol in aqueous solution. J. Environ. Sci. Eng. 2008, 5, 27-30.

17. Duan, X.Y.; Sui, X.Y.; Wang, W.Y.; Bai, W.H.; Chang, L.M. Fabrication of $\mathrm{PbO}_{2} / \mathrm{SnO}_{2}$ composite anode for electrochemical degradation of 3-chlorophenol in aqueous solution. Appl. Surf. Sci. 2019, 494, 211-222. [CrossRef]

18. Aslama, M.; Tahir Soomroa, M.; Ismail Iqbal, M.I.; Salah, N.; Gondald, M.A.; Hameed, A. Sunlight mediated removal of chlorophenols over tungsten supported ZnO: Electrochemical and photocatalytic studies. J. Environ. Chem. Eng. 2015, 15, 1901-1911. [CrossRef]

19. Mozia, S.; Bubacz, K.; Janus, M.; Morawski, A.W. Decomposition of 3-chlorophenol on nitrogen modifified TiO 2 photocatalysts. J. Hazard. Mater. 2012, 203-204, 128-136. [CrossRef]

20. Shen, X.Q.; Xiao, F.; Zhao, H.Y.; Chen, Y.; Fang, C. In Situ-Formed PdFe Nanoalloy and Carbon Defects in Cathode for Synergic Reduction-Oxidation of Chlorinated Pollutants in Electro Fenton Process. Environ. Sci. Technol. 2020, 54, 4564-4572. [CrossRef]

21. Sun, Z.R.; Wei, X.F.; Zhang, H.; Hu, X. Dechlorination of pentachlorophenol (PCP) in aqueous solution on novel Pd-loaded electrode modified with PPy-SDBS composite film. Environ. Sci. Pollut. Res. 2015, 22, 3828-3837. [CrossRef] [PubMed]

22. Xie, W.J.; Yuan, S.H.; Mao, X.H.; Hu, W.; Liao, P.; Tong, M. Electrocatalytic activity of Pd-loaded Ti/TiO 2 nanotubes cathode for TCE reduction in groundwater. Water Res. 2013, 4, 3573-3582. [CrossRef] [PubMed]

23. Sun, Z.R.; Zhang, J.W.; Wang, X.Y.; Hu, X. Electrochemically reductive dechlorination of 2,4,6-trichlorophenol on palladium loaded titanium cathode modified with graphene/polymeric pyrrole-sodium dodecyl benzene sulfonate. Desalin. Water Treat. 2017, 88, 128-138. [CrossRef]

24. Cai, X.; Matsunaga, A.; Tezuka, M. Electroreductive dechlorination of chlorophenols with Pd catalyst supported on solid electrode. J. Environ. Sci. 2013, 25, 151-154.

25. Yang, B.; Yu, G.; Liu, X.T. Electrochemical hydrodechlorination of 4-chlorobiphenyl in aqueous solution with the optimization of palladium-loaded cathode materials. Electrochim. Acta 2006, 52, 1075-1081. [CrossRef]

26. Zhang, L.; Lu, T.; Bao, J.; Tang, Y.; Li, C. Preparation method of an ultrafifine carbon supported Pd-catalyst as an anodic catalyst in a direct formic acid fuel cell. Electrochem. Commun. 2006, 8, 1625-1629. [CrossRef]

27. Sun, Z.; Ge, H.; Hu, X.; Peng, Y. Electrocatalytic dechlorination of chloroform in aqueous solution on palladium/titanium electrode. Chem. Eng. Technol. 2009, 32, 134-139. [CrossRef]

28. Liu, Y.; Yang, F.; Yue, P.; Chen, G. Catalytic dechloronation of chlorophenols in water by palladium/iron. Water Res. 2001, 35, 1887-1890. [CrossRef]

29. Andrey, I.; Yamanaka, I.; Otsuka, K. Pd-Loaded Carbon Felt as the Cathode for Selective Dechlorination of 2,4-Dichlorophenoxyacetic Acid in Aqueous Solution. J. Electrochem. Soc. 1998, 145, 3844-3850.

30. Zhou, J.S.; Lou, Z.M.; Yang, K.L.; Xu, J. Electrocatalytic dechlorination of 2,4-dichlorobenzoic acid using different carbonsupported palladium moveable catalysts: Adsorption and dechlorination activity. Appl. Catal. B Environ. 2019, 44, $215-224$. [CrossRef]

31. Scialdone, O.; Corrado, E.; Galia, A.; Sirés, I. Electrochemical process and cell for the abatement of an unsaturated organic species from an aqueous solution. Electrochim. Acta 2014, 132, 15-19. [CrossRef] 
32. Hu, B.; Wu, C.; Zhang, Z.; Wang, L. Sonophotocatalytic degradation of trichloroacetic acid in aqueous solution. Ceram. Int. 2014, 40, 7015-7021. [CrossRef]

33. Melnick, R.L.; Nyska, A.; Foster, P.M.; Roycroft, J.H.; Kissling, G.E. Toxicity and carcinogenicity of the water disinfection byproduct, dibromoacetic acid, in rats and mice. Toxicology 2007, 230, 126-233. [CrossRef]

34. Hong, S.; Min, Z.W.; Mok, C.; Kwon, H.; Kim, T.; Kim, D. Aqueous degradation of imidacloprid and fenothiocarb using contact glow discharge electrolysis: Degradation behavior and kinetics. Food Sci. Biotechnol. 2013, 22, 1773-1881. [CrossRef] 